\title{
notes from the cover
}

\author{
Magie Dominic
}

\begin{abstract}
Notes from the cover a commencé comme une liste de mots, sans émotion, sans commentaire rédactionnel. Cette liste a été difficile à mettre sur papier, mais à la fin, chaque mot a pris place de lui-même, faisant naître des groupes de mots et, finalement, la structure même du poème. Notes from the cover évoque la notion de reconstruction, d'un mot l'autre, quelles que soient les cassures. Le poème évoque la plongée au fond d'un océan de vie et le geste qui consiste à s'accrocher à une branche ou à une brindille.
\end{abstract}

the woman who wanted to write this poem declined.

finding none who shared her language.

$i$ am speaking for her.

she had no idea her seven-year-old heart would sit in a car

under newfoundland trees

while an old man had his way with her

sunday after bloody sunday

and she'd search forever for safety,

(one reason she's not here now)

had no idea her heart would know experiences

"growing up"

so unspeakable they remain unwritten.

would be beaten by nuns wearing jesus

and sung to by others.

would stand in a hallway

trying to calm

the rapist with a knife to her head

talking

as if her life depended on it

then fall to the floor

wordless.

would stand on flatbed trucks screaming sixties poems about napalm

and burning flesh through manhattan microphones

and years later find herself unable

to whisper the unbearable

pain in her heart. 
would so often have nearby a book and a cup of tea, could be in any country in any century, only the radio gave her away.

would light so many candles

know the names of so many saints (and their addresses) would walk through the heroin darkness of a lover's apartment, slap him to consciousness, convince him to walk with her again. she did this often (who was convincing who, she wonders now?) (who in god's name?)

would move her family so many times trying to save what was already lost.

would

walk silently on early vancouver mornings, pick bottles from sidewalks, go to the unquestioning chinese grocer, exchange everything for eggs and bread, (food for a child) she did this while the father/husband slept beneath detachment's blankets.

had no idea her heart could hold so many memories.

would one day tell this father/husband she was leaving now and walked to the blue station wagon under trees with a child on one arm and rage swept from the coals of her heart on the other. (abuse of other human beings is against the law)

(it took this woman an eternity to believe she was sleeping with a criminal) 
would go running through aids wards

howling for blankets for friends dying cold.

could not keep tears from her face

as these friends turned

to skeletons, time running out,

a rolex ticking on bone,

remembered the one left dead in mexico's desert, a lover panicked, searching for cures, afraid now with a dead body in the car

(how exactly do you explain all this to customs)

had no idea her heart would travel

trying to find itself again,

had no idea it would feel so invisible

could feel so afraid.

would fall in love with so many women, so many brave healers, and some of them with her.

would write so many poems about death read so many

and write so many obituaries.

would take so many risks to save herself.

would one day in thin clothing stand on her front steps not caring what the neighbors thought, yell with a voice pulled from the throat of a god

"tell the truth you bastard, tell the truth you bastard."

the woman who wanted to write this poem declined.

i saw only the cover of her notebook.

(what things are written inside)

her heart allowed me to see no more.

her heart wrapped in feathers

and lace,

guarded fiercely by angels. 